\title{
Prevalence of Major Cardiovascular Risk Factors among Adults in Albania
}

\author{
Ormir Shurdha ${ }^{1}$, Endri Hasimi ${ }^{1}$, Elizana Petrela ${ }^{2}$, Prof Artan Goda ${ }^{1}$ \\ ${ }^{1}$ University Hospital Centre "Mother Teresa" Tirana \\ ${ }^{2}$ Department of Public Health, Tirana
}

\begin{abstract}
Background: Approximately 80\% of cardiovascular disease (CVD) can be explained by smoking, hypertension, and deterioration of lipid and glucose metabolism. The aim of this study is to determine the spread of cardiovascular risk factors in a sample from the Albanian population. Methodology: 632 persons were randomly selected: consisting of 443 females and 189 males. The inclusion criteria were males and females above 18 years old. The selection was random, one person per house, stratified by address, gender and age group. We registered the conventional risk factors for coronary heart disease such as smoking, alcohol, hypertension, diabetes mellitus etc. as well as sociodemographic and socioeconomic characteristics. Results: 632 persons were included in this survey, consisting of 189 (29.9\%) males and 443 (70.1\%) females. The average age in males was $43.90 \pm 15.57$ years old, whereas in females it was $38.54 \pm 12.51$. The prevalence of hypertension in this population is $16.10 \%$, and males have slightly higher prevalence than females but without a statistically significant difference, $20.4 \%$ vs. $14.2 \%$ respectively $(p=0.015)$. The prevalence of smoking was $20.3 \%$, and males smoke more than women, $33.5 \%$ vs. $14.7 \%$ respectively $(p<0.001)$. About $46.1 \%$ of males and $39.9 \%$ of females have high cholesterol $\geq 200 \mathrm{mg} / \mathrm{dL}(p=0.231)$ and the prevalence of diabetes mellitus was $4.6 \%$, being higher in males than in females, 9.1\% vs 2.7\% respectively ( $=0.001)$. Conclusion: There is a high prevalence of cardiovascular risk factors in our population. Thus, a considerable percentage of the Albanian population has a "high risk" for future cardiovascular events.
\end{abstract}

Keywords: CVD risk factors, prevalence, smoking, hypertension, dyslipidemia, diabetes mellitus

\section{Introduction}

Cardiovascular disease (CVD) remains the most important cause of death worldwide. More than 17 million people died from CVD in 2008, and 10\% of the global disease burden, as measured in disability-adjusted life-years, is attributed to CVD. More than 3 million of these deaths occurred in people below the age of 60 and could have largely been prevented $^{1}$. The percentage of premature deaths from CVD ranges from $4 \%$ in high-income countries to $42 \%$ inlowincome countries, and there are growing inequalities in the occurrence and outcome ofCVD between countries and social classes. Over recent decades, CVD deaths have been declining in high-income countries, but have been increasing rapidly in low- and middle-income countries.

The epidemic of cardiovascular disease (CVD) in the twentieth century prompted many population-based surveys. Now, a huge number of epidemiological studies provide a clear picture of the risk for CVD. Approximately $80 \%$ of CVD can be explained by smoking ${ }^{2-5}$, high blood pressure ${ }^{6,}$ 7 , and deterioration of lipid and glucose metabolism ${ }^{8,9}$, the two latter being mediated through an unhealthy diet (high intake of salt, saturated fat, and refined sugar)and physical inactivity $^{10,11}$. A causal web for CVD shows that the influence is seen throughout the life course, and that „upstream "e factors like socioeconomic status, health policies, and industrial influences all have a powerful impact on the more downstream parameters like lifestyle and biomarkers. This emphasizes that population-level interventions represent the most effective options for future strategies for the prevention of $\mathrm{CVD}^{12}$.

Albania represents some peculiarities regarding its epidemiologic profile. While its mortality models resemble those of developed European countries, its morbidity models resemble those of developing countries ${ }^{13}$.

\section{Objective}

To determine the spread of cardiovascular risk factors such as hypertension, smoking, blood lipids and glucose in a sample from the Albanian population.

\section{Methodology}

For this study we used the data from the international project: "National study on nutrition habits and prevalence of the cardiovascular risk factors in the Albanian population". The inclusion criteria were males and females over 18 years old. The sample selection was random, one person per house stratified by address, gender and age group. We took blood tests of fasting patients: total cholesterol, triglycerides (TG), Low Density Lipoproteins Cholesterol (LDL-cholesterol), High Density Lipoproteins Cholesterol (HDL-cholesterol) and glucose.

All the participants had to fill in a form which included socio-demographic and socio-economic characteristics such as age, gender, education, job, economic level, social stratum and religion. The socio-economic level was determined based on the actual professional status; education level categorized as primary, high and higher education; actual marital status; and economic status categorized into 2 levels: category A - mean monthly income of the last 3 years $<20.000$ ALL $(\sim 143$ EUR) - and category $\mathrm{B}-$ mean monthly income of the last 3 years > 20.000 ALL.

\section{Volume 4 Issue 12, December 2015}




\section{International Journal of Science and Research (IJSR) \\ ISSN (Online): 2319-7064}

Index Copernicus Value (2013): 6.14 | Impact Factor (2014): 5.611

We also registered the conventional risk factors for ischemic heart disease such as smoking, alcohol, sedentary life, hypertension, diabetes, family history of ischemic heart disease and anthropometric indices. Dyslipidemia was defined according to the ATP III criteria: High Total Cholesterol (TC) $\geq 200 \mathrm{mg} / \mathrm{dL}$, high LDL-cholesterol (LDLC) $\geq 130 \mathrm{mg} / \mathrm{dL}$, low HDL-cholesterol (HDL-C) $\leq 40$ $\mathrm{mg} / \mathrm{dL}$, Hypertriglyceridemia (TG) $\geq 150 \mathrm{mg} / \mathrm{dL}$.

Individuals were classified as hypertensive when systolic blood pressure was higher than $140 \mathrm{~mm} \mathrm{Hg}$ and/or diastolic blood pressure was higher than $90 \mathrm{~mm} \mathrm{Hg}$. Hypertension was defined according to hypertension guidelines ${ }^{5}$. Blood Systolic $(\mathrm{mm} \mathrm{Hg}) /$ Diastolic $(\mathrm{mm} \mathrm{Hg})$ pressure was categorized as Normal 120-129/80-84; High Normal 130139/85-89; and Hypertension stages: Stage 1 - mildly elevated 140-159/90-99; Stage 2 - moderately elevated 160179/100-109; Stage 3 - highly elevated 180+/110+. Also, following international recommendations, the interviewees were considered hypertensive even when they had normal or optimal blood pressure, but were taking anti-hypertensive medications.

\section{Statistical Analysis}

The data were presented in absolute values and in percentage. The Chi-square test was used to evaluate differences among groups. Random associations among variables were analyzed through binary logistic regression. Whereas the Kolmogorov-Smirnov test was used to evaluate differences within the groups. The statistical analysis was made with the SPSS 19.0 software.

\section{Results}

This study included 632 persons, which consisted of 189 $(29.9 \%)$ males and $443(70.1 \%)$ females. The average age of males was $43.90 \pm 15.57$ years old, whereas that of females was $38.54 \pm 12.51$ years old. Table 1 presents the spread of socio-demographic characteristics according to gender. There were no statistically significant differences between males and females regarding education, marital status and economic situation. As regards education, about half of the participants had higher education degrees.

Table 1: Socio-demographic characteristics according to gender

\begin{tabular}{|c|c|c|c|c|c|}
\hline \multirow{2}{*}{\multicolumn{2}{|c|}{ General characteristics }} & \multicolumn{2}{|c|}{ Gender } & \multirow{2}{*}{$\begin{array}{c}\text { Total } \\
\mathrm{n}=632(\%)\end{array}$} & \multirow[t]{2}{*}{ p value } \\
\hline & & $\mathrm{M} \mathrm{n}=189(\%)$ & $\mathrm{F} \mathrm{n}=443(\%)$ & & \\
\hline \multirow[t]{5}{*}{ Education } & primary & $12(6.4)$ & $37(8.4)$ & $49(7.8)$ & \multirow[t]{5}{*}{0.901} \\
\hline & high & $56(29.6)$ & $127(28.7)$ & $183(29.0)$ & \\
\hline & higher & $85(45.0)$ & $196(44.2)$ & $281(44.5)$ & \\
\hline & elementary & $1(0.5)$ & $2(0.5)$ & $3(0.5)$ & \\
\hline & not reported & $35(18.5)$ & $81(18.3)$ & $116(18.4)$ & \\
\hline \multirow[t]{5}{*}{ Marital status } & single & $54(28.6)$ & $133(30.0)$ & $187(29.6)$ & \multirow[t]{5}{*}{0.505} \\
\hline & divorced & $1(0.5)$ & $8(1.8)$ & $9(1.4)$ & \\
\hline & window & $3(1.6)$ & $10(2.3)$ & $13(2.1)$ & \\
\hline & married & $116(61.4)$ & $257(58.0)$ & $373(59.0)$ & \\
\hline & & $15(7.9)$ & $35(7.9)$ & $50(7.9)$ & \\
\hline \multirow[t]{3}{*}{ Economic status } & $\mathrm{A}(<20.000 \mathrm{ALL})$ & $33(17.5)$ & $132(29.8)$ & $165(26.1)$ & \multirow[t]{3}{*}{0.007} \\
\hline & $\mathrm{B}(<20.000 \mathrm{ALL})$ & $122(64.6)$ & $242(54.6)$ & $364(57.6)$ & \\
\hline & & $34(18.0)$ & $69(15.6)$ & $103(16.3)$ & \\
\hline \multirow[t]{5}{*}{ Religion } & Bektashi & $13(6.9)$ & $25(5.6)$ & $38(6.0)$ & \multirow[t]{5}{*}{0.952} \\
\hline & Catholic & $16(8.5)$ & $34(7.7)$ & $50(7.9)$ & \\
\hline & Muslim & $103(54.5)$ & $255(57.6)$ & $358(56.6)$ & \\
\hline & Orthodox & $32(16.9)$ & $80(18.1)$ & $112(17.7)$ & \\
\hline & Other & $25(13.2)$ & $49(11.1)$ & $74(11.7)$ & \\
\hline
\end{tabular}

As regards the economic status of the participants, there was a statistically significant difference between categories: Category A (mean monthly income of the last 3 years < 20.000 ALL) was $26.7 \%$ whereas Category B (mean monthly income of the last 3 years $>20.000$ ALL) was $58.8 \%(\mathrm{p}<0.001)$.

\section{Clinical and biochemical data}

The mean systolic blood pressure was $123.9 \mathrm{~mm} \mathrm{Hg}$ in males and $120.03 \mathrm{~mm} \mathrm{Hg}$ in females and there was no statistically significant difference between genders; whereas the mean arterial diastolic pressure was higher in females than in males, $81.17 \mathrm{~mm} \mathrm{Hg}$ vs. $77.53 \mathrm{~mm} \mathrm{Hg}$ respectively $(\mathrm{p}<0.01)$ (Table 2). The prevalence of hypertension in this population was $16.10 \%$, and males have a slightly higher prevalence than females but without a statistically significant difference, $20.40 \%$ vs. $14.20 \%$ respectively $(\mathrm{p}=0.015)$. One every four persons reported having family history for hypertension. The prevalence of hypertension increases proportionally with age (Table 3). Thus, the percentage of normal blood pressure decreases with increasing age, in accordance with the increasing prevalence of hypertension (hypertension stage 1,2 and 3) with increasing age. 
International Journal of Science and Research (IJSR)

ISSN (Online): 2319-7064

Index Copernicus Value (2013): 6.14 | Impact Factor (2014): 5.611

Table 2: Clinical characteristics of participants according to gender

\begin{tabular}{|c|c|c|c|}
\hline \multirow[b]{2}{*}{ Variables } & \multicolumn{2}{|c|}{ Gender } & \multirow[b]{2}{*}{ p value } \\
\hline & $M n=189(\%)$ & F $n=443(\%)$ & \\
\hline Age (years) & $43.90 \pm 15.57$ & $38.54 \pm 12.51$ & $<0.001$ \\
\hline SBP & $123.912 \pm 16.35$ & $120.03 \pm 19.77$ & 0.028 \\
\hline DBP & $81.17 \pm 8.79$ & $77.53 \pm 11.16$ & $<0.001$ \\
\hline Glucose & $82.88 \pm 14.5$ & $85.43 \pm 15.56$ & 0.269 \\
\hline Total Cholesterol & $197.24 \pm 12.41$ & $202.33 \pm 10.03$ & 0.231 \\
\hline HDL-cholesterol & $48.59 \pm 7.98$ & $48.48 \pm 7,12$ & 0.911 \\
\hline LDL-cholesterol & $119,39 \pm 11,4$ & $122.51 \pm 7,74$ & 0.362 \\
\hline TG & $116,63 \pm 8.98$ & $120.45 \pm 9.76$ & 0.216 \\
\hline BMI & $26.69 \pm 4.10$ & $24.94 \pm 5.34$ & $<0.001$ \\
\hline Waist circumference $(\mathrm{cm})$ & $94.37 \pm 15.41$ & $78.85 \pm 16.03$ & $<0.001$ \\
\hline Hip circumference $(\mathrm{cm})$ & $102.89 \pm 9.98$ & $100.07 \pm 10.28$ & 0.008 \\
\hline
\end{tabular}

Table 3. Prevalence of arterial hypertension according to age groups

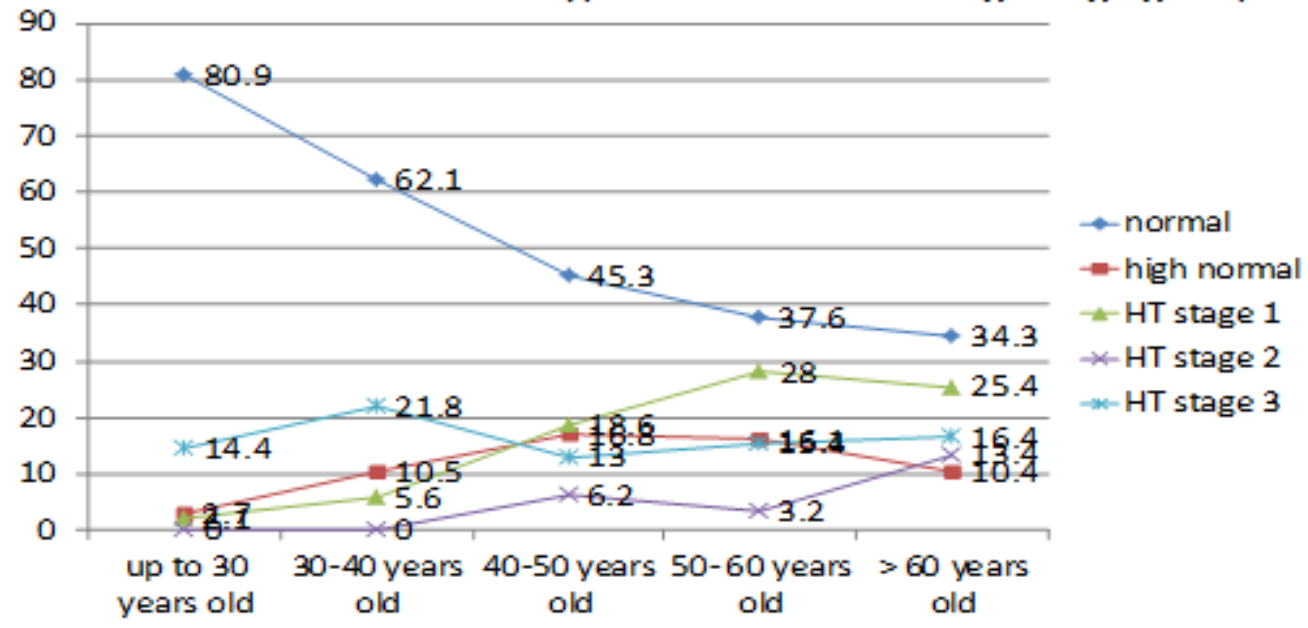

The prevalence of smoking is $20.30 \%$, and males smoke more than females, $33.50 \%$ vs. $14.7 \%$ respectively $(\mathrm{p}<0.001) \quad$ (Table 4). As regards the demographic characteristics, there is a statistically significant difference between smokers and non-smokers regarding gender $(\mathrm{p}<0.001)$, whereas there are no statistically significant differences regarding education, marital status, economic status, religion and age groups.

Table 4: Prevalence of cardiovascular risk factors according to gender

\begin{tabular}{|c|c|c|c|c|}
\hline \multirow{2}{*}{ Risk factor } & \multicolumn{2}{|c|}{ Gender } & \multirow{2}{*}{$\begin{array}{c}\text { Total } \\
(n=632\end{array}$} & $\begin{array}{c}p \\
\text { value }\end{array}$ \\
\cline { 2 - 3 } & $\begin{array}{c}M \\
(n=189)\end{array}$ & $F(n=443)$ & & \\
\hline Actual smoker & $61(32.3)$ & $63(14.2)$ & $124(19.6)$ & $<0.001$ \\
\hline Alcohol & $131(69.3)$ & $186(42.0)$ & $317(50.2)$ & $<0.001$ \\
\hline HTN & $38(20.1)$ & $63(14.2)$ & $101(16.0)$ & 0.015 \\
\hline $\begin{array}{c}\text { Family history for } \\
\text { HTN }\end{array}$ & $51(27.0)$ & $122(27.5)$ & $173(27.4)$ & 0.837 \\
\hline $\begin{array}{c}\text { Diabetes Mellitus } \\
\text { (DM) }\end{array}$ & $17(9.1)$ & $12(2.7)$ & $29(4.6)$ & 0.001 \\
\hline $\begin{array}{c}\text { Family history for } \\
\text { DM }\end{array}$ & $25(13.2)$ & $52(11.7)$ & $77(12.2)$ & 0.629 \\
\hline Diet & $29(15.3)$ & $68(15.3)$ & $97(15.3$ & 0.925 \\
\hline
\end{tabular}

Total cholesterol was $197.24 \mathrm{mg} / \mathrm{dL}$ in males and 202.33 $\mathrm{mg} / \mathrm{dL}$ in females $(\mathrm{p}=0.231)$; LDL-cholesterol was 119.30 $\mathrm{mg} / \mathrm{dL}$ in males and $122 \mathrm{mg} / \mathrm{dL}$ in females $(\mathrm{p}=0.362)$. HDLcholesterol was $48.59 \mathrm{mg} / \mathrm{dL}$ in males and $48.48 \mathrm{mg} / \mathrm{dL}$ in females $(p=0.911)$. TG was $116.63 \mathrm{mg} / \mathrm{dL}$ in males and 120 $\mathrm{mg} / \mathrm{dL}$ in females $(\mathrm{p}=0.215)$.
The prevalence of dyslipidemia in our population was $58.6 \%$. Total hypercholesterolemia (TC $\geq 200 \mathrm{mg} / \mathrm{dL}$ ) was high, being present in $44.3 \%$ of the population, and women have a higher prevalence than men but without any statistically significant difference, $46.1 \%$ vs.39.9\% respectively $(\mathrm{p}=0.231)$. The prevalence of LDL-C $(\geq 130$ $\mathrm{mg} / \mathrm{dL})$, HDL-C $(\leq 40 \mathrm{mg} / \mathrm{dL})$ and TG $(\geq 150 \mathrm{mg} / \mathrm{dL})$, was $34 \%, 17.2 \%, 22.6 \%$ respectively (Table 5 ).

Table 5: Prevalence of dyslipidemia according to ATP III criteria

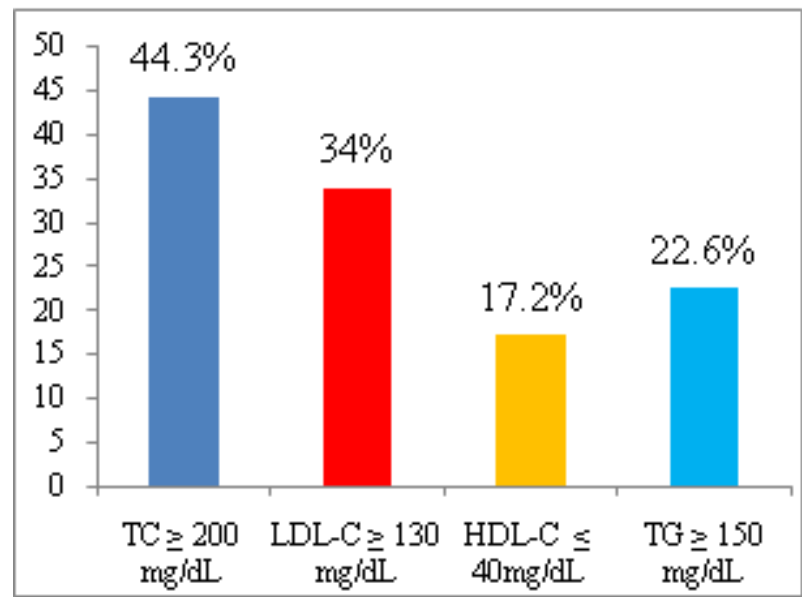

There was no statistically significant difference in blood glucose according to gender. Blood glucose was $82.8 \mathrm{mg} / \mathrm{dL}$ in males and $85 \mathrm{mg} / \mathrm{dL}$ in females $(p=0.269)$. The 


\section{International Journal of Science and Research (IJSR) \\ ISSN (Online): 2319-7064}

Index Copernicus Value (2013): 6.14 | Impact Factor (2014): 5.611

prevalence of diabetes was $4.6 \%$ and it was higher in males than females, $9.1 \%$ vs. $2.7 \%$ respectively $(p=0.269)$.

At the same time, males had a higher body mass index than females, $26.69 \pm 4.10$ vs. $24.94 \pm 5.34$ respectively $(p<0.001)$. Males had a higher waist circumference than females, $94.37 \pm 15.41$ vs. $78.85 \pm 16.03$ respectively $(p<0.001)$, whereas there was no statistically significant difference regarding hip circumference $(\mathrm{p}=0.008)$. About half of the population drinks alcohol, with 3 every 4 males and 2 every 5 females answering "Yes" to the question regarding alcohol use.

\section{Discussion}

The mean systolic blood pressure was $123.9 \mathrm{~mm} \mathrm{Hg}$ in males and $120.03 \mathrm{~mm} \mathrm{Hg}$ in females and there was no statistically significant difference between genders, whereas the mean diastolic blood pressure was higher in women than in men, $81.17 \mathrm{~mm} \mathrm{Hg}$ vs. $77.53 \mathrm{~mm} \mathrm{Hg}$ respectively $(p<0.01)$. In spite of these measurements, a high percentage of participants had high values of both systolic and diastolic blood pressure. The prevalence of hypertension in this population was $16.10 \%$, and males had a slightly higher prevalence than females but without any statistically significant difference, $20.40 \%$ vs. $14.20 \%$ respectively $(p=0.015)$. These values are similar to the other studies conducted with the Albanian population ${ }^{14}$. This study also confirmed that hypertension is proportional to age even in this population.

The prevalence of smoking was $20.30 \%$, and males smoke more than females, $33.50 \%$ vs. $14.7 \%$ respectively $(\mathrm{p}<0.001)$. These results are similar to a study conducted in 2003-2006 in which the prevalence of smoking in the normal population was $34.4 \%$ in males and $13.7 \%$ in females ${ }^{15}$. In all the European countries (except for Sweden), the prevalence of smoking is higher in males than in females. This difference is more noticeable in Eastern European countries than in Western Europe ${ }^{16}$.

The prevalence of dyslipidemia in our population was $58.6 \%$, which is similar to the other European countries. Thus, we can speculate that about 1.4 million Albanians have at least one of the high dyslipidemia risk factors. Total hypercholesterolemia ( $\mathrm{TC} \geq 200 \mathrm{mg} / \mathrm{dl}$ ) is high, in $44.3 \%$ of the population, and females have a higher prevalence than males, but no statisticially significant difference, $46.1 \%$ vs. $39.9 \%$ respectively $(p=0.231)$. The prevalence of LDL-C $(\geq 130 \mathrm{mg} / \mathrm{dl})$, HDL-C $(\leq 40 \mathrm{mg} / \mathrm{dl})$ and TG $(\geq 150 \mathrm{mg} / \mathrm{dl})$ were $34 \%, 17.2 \%$ and $22.6 \%$ respectively. Dyslipidemia is not associated to age groups, BMI, education and family income, but it is associated to fasting blood glucose.

The mean blood glucose was $82.8 \mathrm{mg} / \mathrm{dL}$ in males and 85 $\mathrm{mg} / \mathrm{dL}$ in females $(\mathrm{p}=0.269)$, without statistically significant difference $(p=0.269)$. The prevalence of diabetes was $4.6 \%$, and it was higher in males than in females, $9.1 \%$ vs. $2.7 \%$ respectively $(\mathrm{p}=0.001)$, which are similar to the results of other studies $^{17}$.

\section{Conclusion}

The objective of this study was to describe the situation of cardiovascular risk factors in a representing sample of the Albanian population. The level of these risk factors is high. However, the association among these factors remains unknown, as well as their relation to the lifestyle and behavior of the participants. Thus, future studies might provide better information regarding the role of these factors in the incidence of ischemic heart disease.

\section{References}

[1] Mendis S, Puska P, Norrving B. (eds). Global atlas on cardiovascular disease prevention and control, 2011. Geneva: World Health Organization.

[2] US Department of Health. The health consequences of smoking: a report of the US Surgeon General, 2004. Washington, DC: Government Printing Office.

[3] Prescott E, Hippe M, Schnohr P, et al. Smoking and risk of myocardial infarction in womenand men: longitudinal population study. Br Med J 1998; 316: 1043.

[4] Floderus B, Cederlöf R, Friberg L. Smoking and mortality: a 21-year follow-up based on the Swedish Twin Registry. Int $J$ Epidemiol 1988; 17: 332-40.

[5] Janghorbani M, Hedley AJ, Jones RB, et al. Gender differential in all-cause and cardiovascular disease mortality. Int J Epidemiol 1993; 22: 1056-63.

[6] Landmesser U, Drexler H. Endothelial function and hypertension. Curr Opin Cardiol 2007; 22: 316-20.

[7] Schiffrin EL, Canadian Institutes of Health Research Multidisciplinary Research Group on Hypertension. Beyond blood pressure: the endothelium and atherosclerosis progression. Am JHypertens 2002; 10: 115S-122S.

[8] Lewington S, Whitlock G, Clarke R, et al. Blood cholesterol and vascular mortality by age, sex, and blood pressure: a meta-analysis of individual data from 61 prospective studies with55, 000 vascular deaths. Lancet 2007; 370: 1829-39.

[9] Briel M, Ferreira-Gonzalez I, You JJ, et al. Association between change in high densitylipo protein cholesterol and cardiovascular disease morbidity and mortality: systematic review and meta-regression analysis. $\mathrm{Br}$ Med J 2009; 338: b92.

[10] Dawber TR, Meadors GF, Moore FE Jr. Epidemiological approaches to heart disease: the Framingham Study. Keys A, Menotti A, Aravanis C, et al. The seven countries study

[11] Welin L, Tibblin G, Svardsudd K, et al. Prospective study of social influences on mortality.

[12] Understanding blood pressure readings". American Heart Association. 11 January 2011.

[13] Albania Demographic and Health Survey 2008-2009, microdata.worldbank.org/index.php/catalog/1321/studydescription

[14] Petrela E, et al. HYPERTENSION IN ALBANIA ArhHig Rada Toksikol 2013;64:479-487

[15] O Shurdha, A goda. Prevalenca e duhanpirjes e krahasuar ne popullatennormaledhe ne ate me Semundjete Arterieve Koronare, Pjese e studimit "CHD Incidence in Tirana: Association with rapid social transition and dietary change" Revista e Kardiologjise 2008, 7, 2:18-24

[16] British heart foundation, 2009

[17] Florian Toti at al..Prevalence of obesity, diabetes and prediabetes in Tirana, the capital of Albania 20102011Endocrine DOI:10.1530/endoabs.32.P78
Abstracts (2013) 32 P782 | 